\title{
ОГЛЯД ПОЛІГРАФІВ ТА МЕТОДІВ ОБРОБКИ ПСИХОФІЗІОЛОГІЧНОЇ ІНФОРМАЦІІ
}

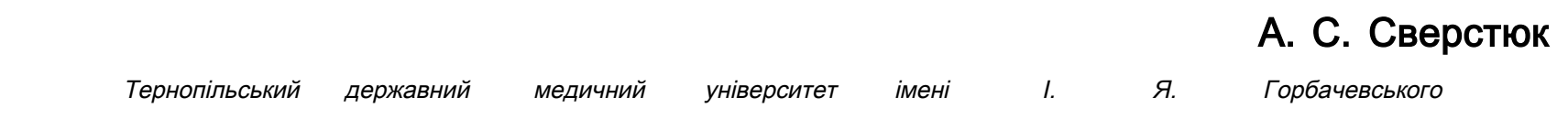

У роботі проведено огляд існуючих поліграфів, методів обробки психоффізіологічної інформації, розглянуто функціональні можливості програмного забезпечення сучасних поліграфів.

Ключові слова: поліграф, методи обробки біосигналів, програмне забезпечення.

\section{ОБЗОР ПОЛИГРАФОВ И МЕТОДОВ ОБРАБОТКИ ПСИХОФИЗИОЛОГИЧЕСКОЙ ИНФОРМАЦИИ}

\author{
А. С. Сверстюк \\ Тернопольский \\ государственный \\ медицинский \\ университет \\ имени \\ и. \\ Я. \\ Горбачевского \\ В работе проведен обзор существующих полиграфов, методов обработки психофизиологической информа- \\ ции, рассмотрены функциональные возможности программного обеспечения современных полиграфов. \\ Ключевые слова: полиграф, методы обработки биосигналов, программное обеспечение.
}

\section{REVIEW OF POLYGRAPHS AND METHODS OF PROCESSING OF PSYCHOPHYSIOLOGICAL INFORMATION}

\author{
A. S. Sverstiuk \\ Ternopil State Medical University by I. Ya. Horbachevsky
}

The paper contains a review of existing polygraph, psychophysiological methods of information, processing there are discussed the means of the modern polygraph software.

Key words: polygraph, methods of biosignals processing, software.

Вступ. Функціонування організму людини як біофізичної системи супроводжується генеруванням електричних, магнітних, механічних полів, змінами дихання, тиску, шкірно-гальванічної реакції, оптичної густини тканин, що у своїй просторово-часовій структурі відображають функціональний стан психофізіологічної системи людини і дають змогу проводити її діагностику та тестування.

Ідеї застосування обстеження на поліграфі грунтуються на факті, що коли людина говорить неправду, змінюються характеристики біосигналів, внаслідок неузгодженості реальної дійсності і модульованої неправдивої інформації.

Поліграф є комплексом, що складається з давачів, сенсорного блоку, комп'ютера та сучасного програмного забезпечення, яким керує фахівець-поліграфолог. Поліграф забезпечує прийом біосигналів від давачів по 7-12 незалежних каналах, дозволяє реєстру(C) А. С. Сверстюк, 2011 вати фотоплетизмограму, шкірно-гальванічну реакцію, верхнє та нижнє дихання, зміни кров'яного тиску, мовний сигнал, автоматичне оцінювання загальної напруженості обстежуваного, психологічну складову в реальному масштабі часу.

Більшість існуючих методів обробки психофізіологічних сигналів грунтуються на математичних моделях у вигляді вектора випадкових величин, стаціонарного випадкового процесу та стохастичного періодичного процесу. Однаку цих математичних моделях не враховуються важливі властивості досліджуваних біосигналів - мінливість та спільність їх ритму.

Наведені вище аргументи вказують на актуальність розробки нової математичної моделі, методів сумісної статистичної обробки та імітації біосигналів на основі теорії випадкових процесів та випадкових полів, для потреб комплексного комп'ютерного обстеження на поліграфі. 
Проведенню огляду існуючих поліграфів, методів обробки психофізіологічної інформації та професійного обстеження на поліграфі присвячена дана робота.

Комп'ютерні поліграфи (КП) та їх основні характеристики. КП складається 3 трьох обов'язкових компонентів: це - апаратна частина („Сенсорний блок" $з$ комплектом датчиків), операційна частина (частина спеціалізованої комп'ютерної програми, що забезпечує оператору поліграфа представлення і зберігання психофізіологічних даних, а також зручність роботи з КП) і система оцінки даних (друга частина спеціалізованої комп'ютерної програми, що здійснює об'єктивний, кількісний аналіз реакцій, зареєстрованих за допомогою КП).

Основними характеристиками КП є:

1) кількість каналів реєстрації, які дають можливість оператору поліграфа більш (або, навпаки, менш) повно стежити за динамікою фізіологічних процесів людини, яка обстежується на поліграфі;
2) наявність надійної та апробованої системи кількісної оцінки зареєстрованих в ході перевірки на КП біосигналів;

3) вигляд інтерфейсу обміну даними з комп'ютером: інтерфейс або змушує купляти КП разом з конкретною моделлю комп'ютера, або дозволяє підключати КП до будь-якого комп'ютера (не нижче певного класу);

4) вид операційної системи, в якій працює спеціалізоване програмне забезпечення КП.

Ефективність використання КП цілком залежить від професіоналізму оператора, який, серед іншого, повинен чудово знати і адекватно застосовувати численні методики перевірок і досконало володіти експертною оцінкою психофізіологічних реакцій людини. Саме оператор визначає підсумкову результативність методу.

У наведеній таблиці 1 , яка складена на підставі офіційної документації фірм-виробників, представлені деякі характеристики КП та аналогово-цифрових перетворювачів (АЦП), які в них використовуються.

Таблиця 1. Основні характеристики КП

\begin{tabular}{|c|c|c|c|c|c|c|}
\hline \multirow{3}{*}{$\begin{array}{c}\text { Назви } \\
\text { КП } \\
\text { поліграфів }\end{array}$} & \multicolumn{6}{|c|}{ Основні характеристики КП } \\
\hline & \multirow{2}{*}{$\begin{array}{c}\text { інтерфейс } \\
\text { обміну } 3 \\
\text { комп'ютером }\end{array}$} & \multirow{2}{*}{$\begin{array}{c}\text { джерело } \\
\text { живлення }\end{array}$} & \multirow{2}{*}{$\begin{array}{c}\text { кількість } \\
\text { незалежних } \\
\text { каналів }\end{array}$} & \multirow{2}{*}{$\begin{array}{c}\text { програмне } \\
\text { забезпечення } \\
\text { (ПЗ) }\end{array}$} & \multicolumn{2}{|c|}{ параметри АЦП } \\
\hline & & & & & $\begin{array}{c}\text { частота } \\
\text { дискретизації, Гц }\end{array}$ & $\begin{array}{c}\text { розрядність } \\
\text { АЦП }\end{array}$ \\
\hline Барьер-14 & RS-232, USB & USB & 9 & Sheriff 6 & 50 & $256^{*}$ \\
\hline Крис & RS-232, USB & USB & 11 & Sheriff-7M & 50 & $256^{*}$ \\
\hline Риф & RS-232, USB & USB & 11 & Sheriff-7M & 50 & $256^{*}$ \\
\hline Эпос-7 & USB & USB & 7 & Нове ПЗ & $8(23$ ФПГ) & $256^{*}$ \\
\hline ПІК-01,02 & USB & USB & 11 & $\begin{array}{l}\text { Архонт, ПКП } \\
\text { «Пік-02» }\end{array}$ & 20 & $4096\left(2^{Л} 12\right)$ \\
\hline $\begin{array}{c}\text { Арсенал } \\
\text { (KARDi2- } \\
\text { NP) }\end{array}$ & USB (HID) & USB & 12 & $\begin{array}{l}\text { Конкорд } \\
\text { Арсенал }\end{array}$ & $\begin{array}{l}125,250,500 \\
2000 \ldots 8000\end{array}$ & $\begin{array}{l}1048576 \\
(2 Л 20)\end{array}$ \\
\hline LX-4000 & USB & USB & 7 & $\begin{array}{c}\text { LXSOFTWARE } \\
(\text { Version 11.0) }\end{array}$ & 120 & 65536 (2Л16) \\
\hline
\end{tabular}

*Ручне управління підсиленням і зміщенням

Усі комп'ютерні поліграфи, які наведені в таблиці, можуть працювати в операційній системі Windows 98/ME/NT/2000/XP.

Особливість моделі поліграфа «Кріс» в тому, що крім реєстрації основних реакцій людського організму, вперше у світовій практиці вирішена задача об'єктивної оцінки функціонального стану людини. При обстеженні фахівець - поліграфолог за допомогою цієї системи оцінки отримує можливість у буквальному сенсі бачити внутрішній світ підозрюваного, прогнозувати та виявляти факти протидії процедурі тестування, визначати його функціональний стан, тобто ступінь готовності обстежуваного до відвертого діалогу і навіть подання свідчень. Для цього використовуються шкали " Самоконтроль", "Внутрішня агресія", "Порушення".

Останні дослідження показують, що точність нових КП "Кріс", "Риф", "Арсенал", "LX4000-SW" становить 95-98 відсотків [1] та у разі проведення компетентним поліграфологом, перевірка на поліграфі $€$ найточнішим доступним засобом визначення правди та неправди.

Відомі методи обробки психофізіологічних сигналів. В основі всіх існуючих методик обробки психофізіологічної інформації лежить реєстрація трьох основних фізіологічних компонент: дихальної, електродермальної та кардіокомпоненти. Для цього використовують від чотирьох до дванадцяти давачів, за 
допомогою яких можна безперервно реєструвати різні фізіологічні характеристики тестованого, i, що дуже важливо, їх зміни в часі.

Основне завдання, що стоїть перед фахівцем-поліграфологом в процесі тестування, - якісно і кількісно оцінити зміну психофізіологічних показників, що реєструються та викликані реакцією на запропоновані питання, і на цій підставі скласти об'єктивний висновок. Крайнощі в стані обстежуваного (спокій, високий рівень збудження) однаково не сприяють підвищенню надійності результатів перевірки. Поліграфічні перевірки найбільш ефективні при " зоні рівня напруги" обстежуваного. Причина цього явища полягає в особливостях регуляції психофізіологічних реакцій нашого організму, що сформувалися в процесі розвитку людини на землі.

Обробка результатів тестування із застосуванням детектора неправди, вирішує дві самостійні проблеми: відбір показників для подальшого аналізу; використання прийомів для отримання достовірних результатів. 3 метою підвищення інформативності та надійності створюються програми, що дозволяють виключити 3 подальшої обробки матеріали, в яких виявляються протидії поліграфа, або є інші спотворення інформації (чхання, чухання тощо). Це здійснюється повторенням питань тестування або простим видаленням перекручених ділянок запису.

На етапі аналізу результатів тестування можна виключити з обробки будь-які канали реєстрації, міняти способи обробки по кожному з них, окремо або разом. Можливо підсумовування будь-яких вимірів і отримання підсумкового результату з 3-5 тестів.

Всі поліграфні системи у світі, в основному, влаштовані за одним принципом: фіксується фон психофізіологічних реакцій людини і зміни фону після отримання відповідної інформації (питання тестових методик). Комп'ютерна програма в автоматичному режимі порівнює та аналізує отримані результати, видаючи достовірність психофізіологічного стресу при відповідях на ті чи інші питання. У стандартний набір психофізіологічних каналів входять: верхнє і нижнє дихання, артеріальний тиск, шкірно-гальванічна реакція, фотоплетизмограма, тремор.

Складність обробки результатів тестування полягає ще й у тому, що доводиться оперувати різними величинами. Наприклад: опір шкіри вимірюється в кілоомах, амплітуда фотоплетизмограми - в мілівольтах або в кубічних міліметрах. 3 метою адекватного порівняння всі показники, які враховуються у використовуваних методиках, приводять до єдиної системи вимірювання, наприклад, переведення їх у відсотки. Для цього всі вихідні (фонові) дані беруться за $100 \%$. У процесі тестування отримані результати фізіологічних реакцій порівнюються з " фоном" у відсотках.

Спосіб перетворення вимірюваних величин у відсотки дозволяє значно підвищити точність кінцевих результатів обстеження на поліграфі. Виявлення можливих реакцій людини можна проводити за готовими "шаблонами". Вони розроблені для кожного каналу і мають список параметрів, за якими відстежується зміна реакцій обстежуваного.

Функціональні можливості програмного забезпечення (ПЗ) сучасних поліграфів. ПЗ сучасних поліграфів дає змогу зберігати понад 100 файлів обстеження. У одному файлі може зберігатися понад 20 поліграм кожного обстежуваного, також передбачена можливість архівації файлів поліграфа i перенесення їх на інші носії.

ПЗ забезпечує можливість створення і зберігання шаблонів тестів $з$ питань, що найчастіше ставляться, що дозволяє уникнути зайвого набору тексту оператором поліграфа. ПЗ передбачає використання тестів наступних типів: метод контрольних питань; модифікований метод загальних питань; метод порівняння зон; тест пікової напруги.

На підставі шаблонів можна створювати тести для конкретних завдань. Питання, включені в шаблон, можуть пред'являтися в довільній послідовності; допускається пропуск або повторне задання питань. На поліграмах питання відображаються в тій послідовності, в якій вони були поставлені.

Фізіологічні реакції відображаються на моніторі в режимі реального часу. ПЗ поліграфів передбачено одночасне виведення поліграм на друк. На поліграмі фіксується послідовність питань, початок і кінець пред'явлення кожного питання, зміст питання i відповідь на нього.

Управління системою здійснюється за допомогою клавіатури або миші (або іншого пристрою-покажчика на портативному комп'ютері). Під час тесту можна змінювати порядок пред'явлення питань, робити позначки на поліграмі, проводити центрування кривих, настроювати коефіцієнти підсилення кожного каналу, які відзначаються на поліграмі.

Записані поліграми можуть відображатися або в тому масштабі, в якому проводився запис, або в стислому: $25 \%, 33$ \% і 100 \% поліграми. ПЗ поліграфів дозволяє здійснювати відображення на екрані декількох поліграм для порівняння реакцій на одне і те ж питання.

Оператор поліграфа може запрограмувати фіксацію 24 різних типів артефактів, таких подій як, на- 
приклад, рухів, кашлю, глибокого вдиху обстежуваного, помилок екзаменатора, шуму всередині або поза приміщенням і позначати їх на поліграмі натисненням певної клавіші.

ПЗ поліграфів забезпечує вивід поліграм в режимі реального часу або після завершення тесту. На роздрукованих поліграмах вказуються початок і кінець пред'явлення питань, відповіді обстежуваного, зміни коефіцієнтів підсилення каналів і центрування кривих, відмітки про особливі події.

Для комп'ютерної обробки отриманих даних в поліграфі LX4000-SW застосовується програмне забезпечення, розроблене Лабораторією Прикладної Фізики (APL) Університету Джона Хопкінса. Це програмне забезпечення реалізує алгоритм аналізу фізіологічної інформації на основі методу статистичних порівнянь. За даними APL, цей алгоритм забезпечує достовірність інтерпретації не менше $95 \%$. Система дозволяє проводити автоматичну обробку поліграм за допомогою наступних методик: порівняння зон; модифікованого методу загальних питань; методу ранжування та тесту стимуляції.

Під час поліграфного обстеження, з метою забезпечення високих імовірнісних, кількісних та якісних результатів, найчастіше використовують тести: Леонарда Килера, Джона Рейда, Клів Бакстера, Девіда Раськіна, Девіда Ліккена, Джозефа Матте і інших.

В даний час багатьма науковцями та дослідниками психофізіологічних сигналів ведуться дослідження у напрямі застосування спектрального аналізу при обробці поліграм. При цьому припускається, що всі зміни фізіологічних процесів в людському організмі представляються у вигляді суми гармонік з частотою від нуля до безкінечності, тоді, застосовуючи методи спектрального аналізу, можна набути чисельних значень внеску кожної частотної складової в часовий генезис вимірюваних параметрів. Дослідження показують, що при прояві неправди тестованого змінюються характеристики за рахунок зміни енергії або величини амплітуди в дуже вузькому частотному діапазоні. За допомогою застосування різних фільтрів виділяються сигнали певних частот, аналізуючи які можна з більшою вірогідністю робити висновки про правдивість або неправдивість тестованого. Отримані результати говорять про можливість мінімізації помилки, навіть в дуже складних випадках, однозначному трактуванні результатів.

Комп'ютерні поліграфи LX4000-SW, LX5KM-SW, LX5000-SW працюють із програмним забезпеченням для поліграфів серії LX, модель LXSoftware. На думку провідних світових поліграфологів, нещодавно презентована в США нова версія LXSoftware (версія 11.0) $\epsilon$ гнучким, досить точним, надійним, зручним та простим у використанні, на основі якого створюються прогресивні, валідні алгоритми обрахунку поліграм [3].

У 2008 році російська компанія «Поліграф Т» розробила програмне забезпечення (ПЗ) «Конкорд АРСЕНАЛ» [4], яке сумісне з багатьма сучасними поліграфами.

Це ПЗ дає можливість проводити визначення досліджуваних ознак, аналізувати показники пульсу та дихання, частотного спектра та фазових співвідношень досліджуваних біосигналів (рис. 1, 2).

ПЗ «Конкорд АРСЕНАЛ» дозволяє провести аналіз особливостей показників плетизмограми і кривих дихання. Порівнюючи біосигнали грудного і діафрагмального дихання можна відстежити зсув фаз між каналами зовнішнього дихання, а також виміряти середні частоти досліджуваних психофізіологічних сигналів.

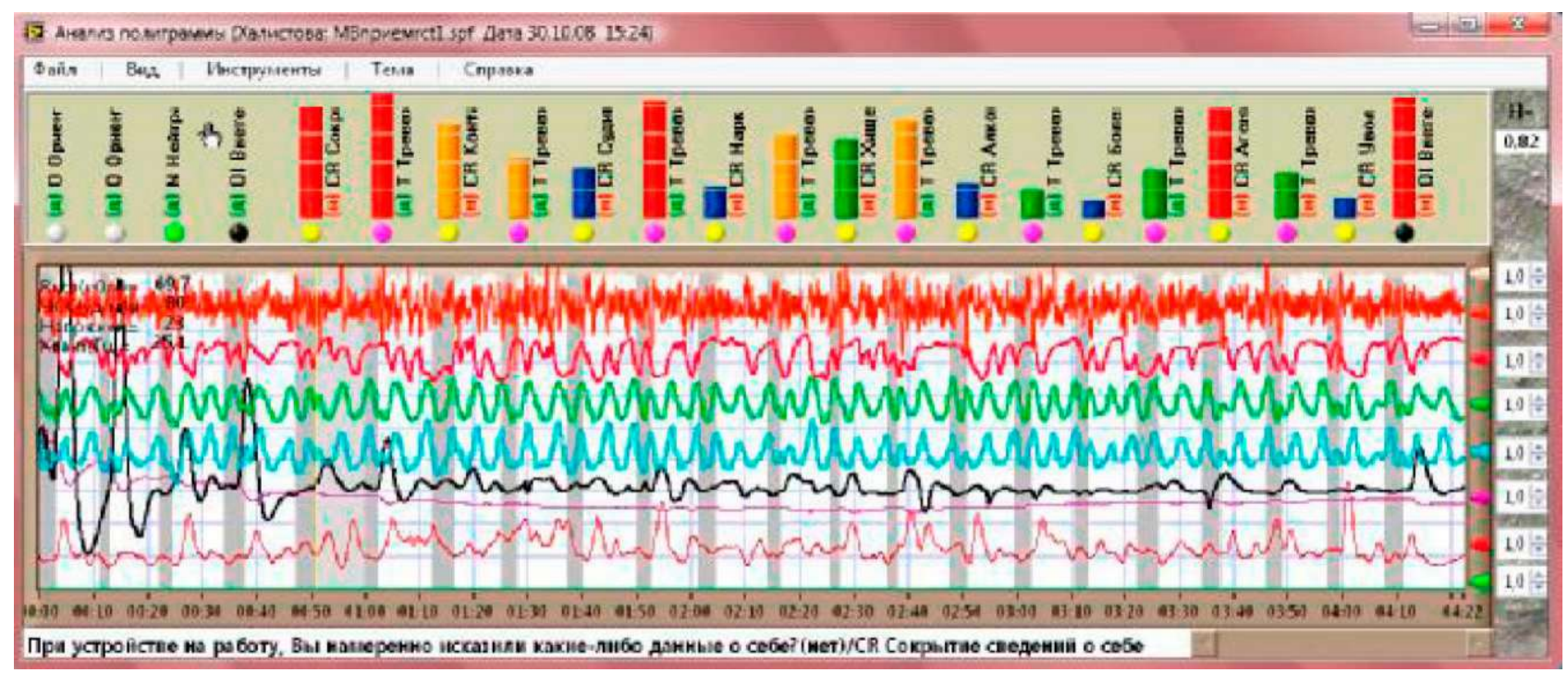

Puc 1. Аналіз поліграми, виконаної поліграфом «АРСЕНАЛ». 


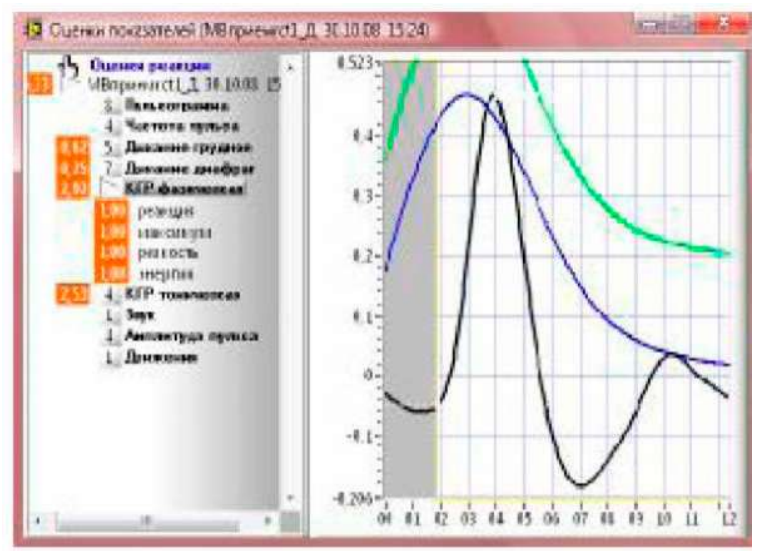

a

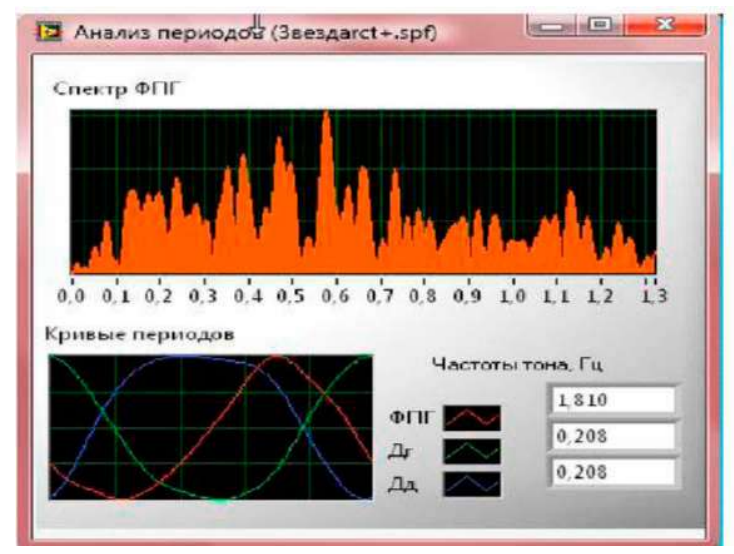

6

Puc. 2. Результати вимірювання ознак (а) та аналізу частотного спектра та фазових співвідношень біосигналів (б) з використанням ПЗ «Конкорд АРСЕНАЛ».

Поліаналізатор дозволяє отримати спільну класифікацію емоційного реагування обстежуваного за матеріалами тестування. Результатом класифікації $\epsilon$ ймовірність невипадкового виникнення емоційного напруження випробуваного на пред' явлені питання у дослідженнях теми.

Звіт за класифікацією представляється у вигляді документа звіту за результатами психофізіологічного тестування, що зберігається у форматі файлів Office Word. Документ містить у собі установчі дані випробуваного (анкета), матеріал тестування 3 оцінками значущості впливу на випробуваного. Крім оцінок впливу кожного питання з стимульного матеріалу, документ містить оцінку надійності всього звіту в цілому.

При класифікації біосигналів використовується ітераційний алгоритм покрокової регресії. Здійснюється пошук функції найкращого поділу реакцій на впливи нейтрального і контрольного характеру. Критерієм оптимальності (збіжності системи рівнянь) служить вираженість і стійкість (невипадковість) реакцій на питання кожної теми. Значення критерію можна розглядати як відношення сигналу емоційної напруги до фізіологічного шуму. Дана оцінка сигнал / шум відображається на екрані та вказує на «надійність звіту», під якою розуміють повторюваність результату класифікації при збереженні рівних умов проведення подібних досліджень на поліграфі.

Функція поділу реакцій нейтрального і контрольного характерів є багатовимірною, ііі розмірність визна- чає сукупність ознак системи методу дослідження.

Побудова функції зводиться до обчислення вагових коефіцієнтів ознак системи. Вагові коефіцієнти об'єднуються в групу залежно від методу дослідження, яка називається патерном.

Патерн представляє собою перелік вагових коефіцієнтів ознак у системі, пов'язаної з методом дослідження. Значення коефіцієнтів вказують на інформативність ознаки при описі емоційної реакції досліджуваного. Іншими словами, патерни описують індивідуальний характер реагування обстежуваної людини в обраній системі ознак (пов'язаної з методом дослідження). Вибір методу класифікації за апріорною значущістю припускає, що матеріал тестування в обов'язковому порядку містить нейтральні і контрольні теми (крім шуканих - перевірочних). При обробці матеріалу класифікатор побудує таку систему ознак, яка оптимально відділить питання контрольного від питань нейтрального типу [5].

Висновки. У роботі проведено огляд існуючих поліграфів, методів обробки психофізіологічної інформації, розглянуто функціональні можливості програмного забезпечення сучасних поліграфів.

У подальших наукових дослідженнях необхідно розробити нову математичну модель, методи сумісної статистичної обробки та імітації біосигналів на основі теорії випадкових процесів та випадкових полів, для потреб комплексного, високоінформативного та достовірного комп'ютерного обстеження на поліграфі.

\section{Лтература}

1. Norman Ansley, "The Validity and Reliability ofPolygraph Decisions in Real Cases," Polygraph, v.19, 1990, pp. 169-181.

4. http://www.poligraft.ru.

5. Оглоблин С. И. Инструментальная "детекция лжи": ака2. П. Экман. Психология лжи : пер. с англ. / Экман П. - СПб.: демический курс/ С. И. Оглоблин, А. Ю. Молчанов. - ЯросПитер, 2001. - 272 с. лавль: Нюанс, 2004. - 464 с.

3. http://www.argo-a.com.ua. 